\title{
Development of an Internal Safety Evaluation Program for Ready Mixed Concrete Producers
}

\author{
Özge AKBOĞA KALE ${ }^{1}$
}

\begin{abstract}
The aim of this study is to assist the safety specialists and departments in ready mixed concrete (RMC) industry by preparing an internal safety evaluation program (ISEP). To constitute an ISEP the 287-item control list was created and grouped as negligible, moderate, and critical. The control list was applied to thirteen RMC plants which belongs to one RMC company. It is found that even the same company cannot ensure stability in terms of OHS between its plants, none of the plants had an approved OHS policy, emergency action plan and a plant entrance OHS warning sign. OHS training was mostly missing in the plants.
\end{abstract}

Keywords: Construction industry, risk identification, control list, risk assessment, safety management system.

\section{INTRODUCTION}

Work-related accidents in the construction industry lead to major problems in many countries [1]. Occupational health and safety (OHS) assurance remains a major challenge because of the diverse and complex nature of this industry. In various studies, researchers have demonstrated that a high percentage of work-related injuries is attributed to construction work. [2-22]. Moreover, the construction industry ranks higher in fatal occupational injuries than in other industries [23-30]. To defuse this high percentage it is necessary to investigate every construction process (excavation works, pile driving, rough construction works, fine construction works, etc.) and sub-sectors (ready mixed concrete industry, prefabricated construction industry, brick plants, etc.) separately because production processes are unique and have differences. Therefore, potential hazards and precautions should be identified for improvement.

The construction industry's single most important material is concrete. Ready mixed concrete (RMC) industry as a producer of the primary material required for buildings and public infrastructure work is one of the most essential sub-sectors of today's construction industry with some specific advantages. Primary advantages of RMC can be listed as follows:

Note:

- This paper was received on March 6, 2020 and accepted for publication by the Editorial Board on September 28, 2020.

- Discussions on this paper will be accepted by May 31, 2020.

- https://doi.org/10.18400/tekderg.699837

1 İzmir Demokrasi University, Department of Civil Engineering, Izmir, Turkey ozge.akbogakale@idu.edu.tr - https://orcid.org/0000-0002-3848-0578 
production of concrete under controlled conditions, easily placement and transportation, reduction of dust pollution, noise and air pollution, higher speed of construction, savings in labor employment, an overall reduction in cost, etc. [31]. Due to the advantages mentioned this product is increasingly being preferred, especially in modern construction, and most developed countries prefer to use RMC instead of conventional concrete production. The United States (274 million m3), Turkey (100 million m3), and Japan (84.8 million m3) are the top three largest producers according to 2018 statistics [32]. In Turkey, the second largest $\mathrm{RMC}$ producer, there has been tremendous growth in RMC production. RMC production was 100 million m3 with 495 RMC companies in 2018 [32].

Academic studies on RMC are abundant. Numerous studies have been conducted to develop ready mixed concrete technology, which is widely in use. However, current studies mostly focus on quality control [33-34], scheduling [35-36], waste management [37-38], delivery problems [39-40], and so on. Since safety and health is a rather new topic in RMC industry, statistical and academic studies are rarely found and limited [41]. Research studies on the subject are not abundant, not only in Turkey but also in other countries. However, when the complex and unique operating system with more component of the industry is taken into consideration, the importance of OHS emerges once again. Publications aiming to build safety awareness are still limited to guidelines and manuals printed by associations such as Occupational Safety and Health Administration (OSHA), American Concrete Pumping Association (ACPA), National Ready Mixed Concrete Association (NSCSA) [42-44]. Besides, there is a high demand for training and consultation regarding occupational safety by RMC companies.

In the interest of filling this gap, the current study has adopted the Internal Safety Evaluation Program to the ready-mixed concrete industry, which has not been applied before. The Internal Safety Evaluation Program (ISEP) provides a structured, documented method of establishing and promoting a system of continual improvement through quality and safety management. ISEP also measures performance and the effectiveness of risk control. The objective of this safety program is to correct non-conformities with risk controls within each specific department's operational processes and to improve the performance of risk controls [45]. A study on how RMC companies will conduct their ISEP will guide them and contribute to the development of OHS policies. To prepare an internal safety evaluation program, it is necessary to consider the functioning of the process in terms of occupational safety and health (OHS).

In addition, it is known that an effective occupational health and safety program contributes to quality management [46]. Total Quality is the handling and development of the management, people, work done, product and service qualities required to meet customer demands in all works performed in any enterprise within a system approach, by ensuring the participation, goals, and consensus of all employees [47]. The concept of occupational safety integrated with the principles of "Total Quality Management", together with the principles of quality and efficiency, constitutes the triple sheet leg that leads the business to success [46]. For this reason, improvement in occupational safety will also benefit total quality management. As a matter of fact, ISO 45001 Occupational Health and Safety Management System standard adopts ISO 14001 Environmental management system and ISO 9001 Quality Management system approaches. Quality assurance systems provide directive 
provisions for ensuring occupational health and safety. Therefore, new programs in the field of occupational safety should be developed, considering the priorities of the industry [48].

The aim of this study is to assist the safety specialists and departments in the industry in making an assessment of the measures it adopts concerning the safety and health of its employees in all fields of its operations in the production of ready mixed concrete by preparing a comprehensive ISEP. The control list is the largest element in a company's internal safety evaluation program. When completed thoroughly, it will be used as the basis for all other areas of the program. For this reason, we investigated what should be considered for detailed ISEP of the production area of a ready mixed concrete plant and a 287-item control list was created. Afterward, the created control list was applied in 13 ready mixed concrete plants of one company. Consequently, the findings of this study will give an opportunity to provide further precautions for preventing future accidents. It is expected that the findings obtained in the study will guide the producers of the ready-mixed concrete sector, advise the occupational safety departments of the producers, inform the occupational safety experts about the sector and inspire researchers.

\section{METHODS}

As organizations move from the early stages to maturity, the focus turns to assuring a continuous safe operation. An Internal Safety Evaluation Program (ISEP) is the prescribed pathway for achieving this objective within a safety management system (SMS) [49]. To have a reliable safety risk assurance under SMS, internal evaluation is a very critical component. ISEP validates the processes, procedures, and controls an organization puts into place and helps ensure they are working as intended. This method also helps verify that risks have been mitigated as low as reasonably practicable [49]. Advantages of ISEP can be listed as follows: it is possible to discover and correct undetected operational risk, operational efficiencies can be promoted, risks can be mitigated to an acceptable level before an event occurs, sheds light on what is working and what is not and so on. ISEP is used in different fields such as flight safety due to its advantages.

The major objective of this study is to determine how to develop a control list for ISEP that can be used by all producers to understand and improve OHS performance in the production process. A framework for the control list should be developed according to sources of risk factors on the site. Therefore, it is necessary to consider the hazards of the complex and unique operating system (Figure 1).

Main hazards in the operation of an RMC production process can be listed as follows:; moving trucks, loaders reversing, trapping between conveyor belts in motion and head/tail drums, falls into aggregate loading hoppers, falling from the upper parts of conveyor belts, impacts from lower parts of moving conveyor belts, falling from upper levels when cleaning filters of silos, trapping, amputations by mixing mechanism, electrocution in the main fuse system, becoming trapped in compressor belts and so on. From this perspective, each stage of the production process outlined in Figure 1 should be examined in terms of OHS. This process is similar in most ready mixed concrete companies. Therefore, it can be said to reflect the general status. In addition to these mechanic hazards, preparing a control list by considering the administrative deficiencies is very important for the companies in the industry to take the necessary importance. The created control list was based on a 
comprehensive literature review, legal regulations, and site visits, including mechanical hazards and safety management system principles.

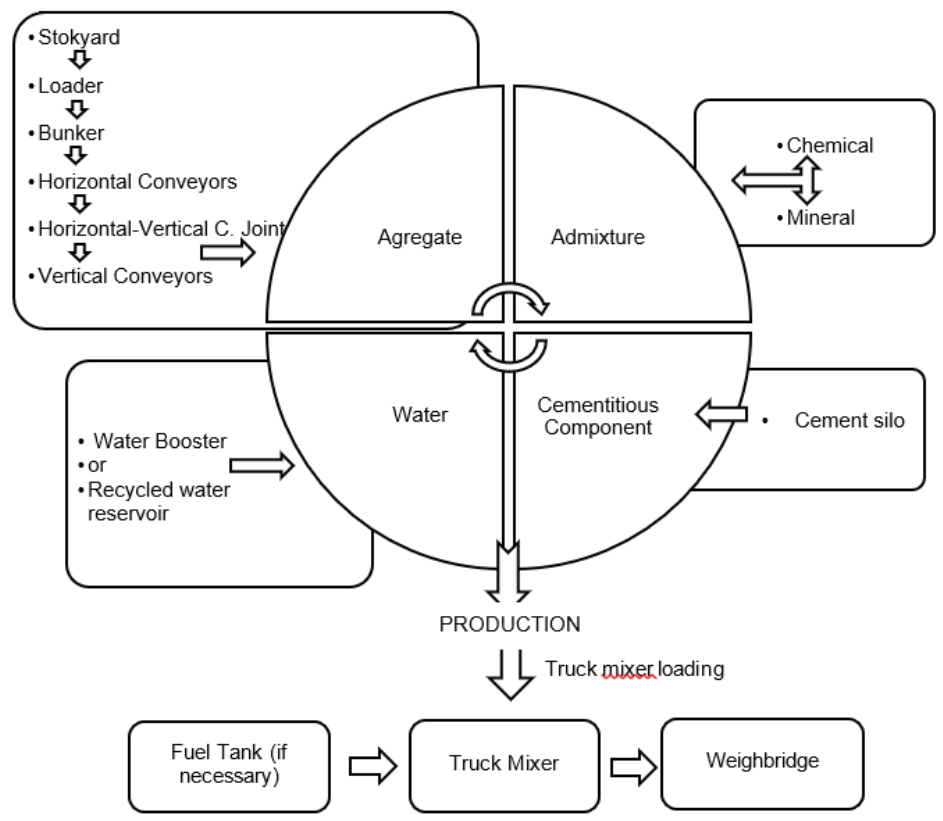

Figure 1 - Flowchart of production.

Within the scope of the created control list, questions were basically grouped under 6 sections namely general, plant, material storage and production, auxiliary facility, mobile equipment, and laboratory. Afterward, the scope of each group was determined as subsections. Within the scope of the general section, managerial OHS precautions were evaluated. Plant entrance, plant entrance OHS warning sign, on-site traffic plan, and plant lighting were investigated under the plant section. Material storage and production section mainly focused production process. Stockyard conformity, bunker conformity, horizontal conveyors, vertical conveyors, horizontal-vertical conveyor joints, mixing process, truck mixer loading, cement silo safety, silo automation, cement trailer unloading, and admixture tank were determined as subsections. Weighbridge, recycled water reservoir, compressor, water booster, generator, fuel tank, operating room, electrical panels, lightning rod, grounding, and transformer AC panel were investigated within the scope of auxiliary facilities. In addition to the production process, also truck mixers, pumps, and loader conformity were evaluated as mobile equipment. Finally, the laboratory was considered. After the process was divided into sections and subsections, a total of 287 safety risks covering the whole process were identified and listed. (Table 1).

Identified safety risk was divided into three groups as negligible, moderate, and critical and their numerical values (NV) were specified as 1,3, and 9, respectively. The purpose of this digitization is to enable the companies to compare their plants numerically and making it 
easier for them to decide where to start improving. The negligible group includes damages probably less than accident or incident levels, moderate groups covers incident to minor accident damage and critical groups include potential loss of life, accident level injury of equipment loss or damage. Since RMC production falls within the very dangerous or moderate groups of risk, critical groups constitute the majority.

Table 1 - Sections of control list.

\begin{tabular}{|c|c|c|c|}
\hline No & Section & Subsection & $\begin{array}{l}\text { List } \\
\text { No }\end{array}$ \\
\hline 1 & General & Managerial OHS precautions & $1-22$ \\
\hline 2 & Plant & $\begin{array}{l}\text { Plant entrance, plant entrance OHS warning sign, on-site traffic plan, plant } \\
\text { lighting }\end{array}$ & $23-50$ \\
\hline 3 & $\begin{array}{l}\text { Material } \\
\text { storage and } \\
\text { production }\end{array}$ & $\begin{array}{l}\text { Stockyard conformity, bunker conformity, horizontal conveyors, vertical } \\
\text { conveyors, horizontal-vertical conveyor joints, mixing process, truck mixer } \\
\text { loading, cement silo safety, silo automation, cement trailer unloading, } \\
\text { admixture tank }\end{array}$ & $\begin{array}{l}51- \\
153\end{array}$ \\
\hline 4 & $\begin{array}{l}\text { Auxiliary } \\
\text { facility }\end{array}$ & $\begin{array}{l}\text { Weighbridge, recycled water reservoir, compressor, water booster, generator, } \\
\text { fuel tank, operating room, electrical panels, lightning rod, grounding, } \\
\text { transformer AC panel }\end{array}$ & $\begin{array}{l}154- \\
227\end{array}$ \\
\hline 5 & $\begin{array}{l}\text { Mobile } \\
\text { equipment }\end{array}$ & Truck mixers, pumps, loader conformity & $\begin{array}{l}228- \\
271\end{array}$ \\
\hline 6 & Laboratory & Laboratory & $\begin{array}{l}272- \\
287\end{array}$ \\
\hline
\end{tabular}

Table 2 - Properties of visited plants.

\begin{tabular}{ccccc}
\hline Plant no & Plant age & $\begin{array}{c}\text { Number of } \\
\text { workers }\end{array}$ & $\begin{array}{c}\text { Number of } \\
\text { trans mixers }\end{array}$ & $\begin{array}{c}\text { Number of } \\
\text { pumps }\end{array}$ \\
\hline 1 & 6 years & 39 & 16 & 4 \\
2 & 5 years & 30 & 9 & 2 \\
3 & 8 years & 39 & 13 & 3 \\
4 & 9 years & 50 & 18 & 4 \\
5 & 9 years & 45 & 16 & 3 \\
6 & 11 years & 28 & 15 & 2 \\
7 & 4 months & 10 & - & - \\
8 & 4 years & 33 & 12 & 3 \\
9 & 3 years & 37 & 13 & 2 \\
10 & 9 years & 56 & 26 & 6 \\
11 & 8 years & 48 & 22 & 5 \\
12 & 4 years & 83 & 37 & 7 \\
13 & 4 years & 75 & 33 & 6 \\
\hline
\end{tabular}


To demonstrate the applicability and the effectiveness of the created control list, it was applied to thirteen ready mixed concrete plants located in different cities of Turkey which belongs to one RMC company in 2018. The general characteristics of the ready mixed concrete plants are presented in Table 2. Site visits were conducted with the technical personnel of each plant. The visited plants were evaluated according to their current status.

Detailed control list presented in the Results section were prepared separately for each section so that it could be followed easily. In the first stage, if there is a measure taken against the risk controlled according to the created control list, it is marked as $(+)$, if not (-). Since each safety risk was digitizing in the control list, the maximum risk score of each section was determined. For example, risk value, which is "135" in Table 3, is the score that would be obtained if no measures were taken regarding this section in the visited facility. With this approach, the risk score of each of the 13 visited facilities was determined by collecting OHS negligence. This process was repeated for each section and presented in separate tables. Finally, the sum of the deficiencies of each plant in all sections for an overall assessment was presented. The flow chart of the methodology is presented in Figure 2.

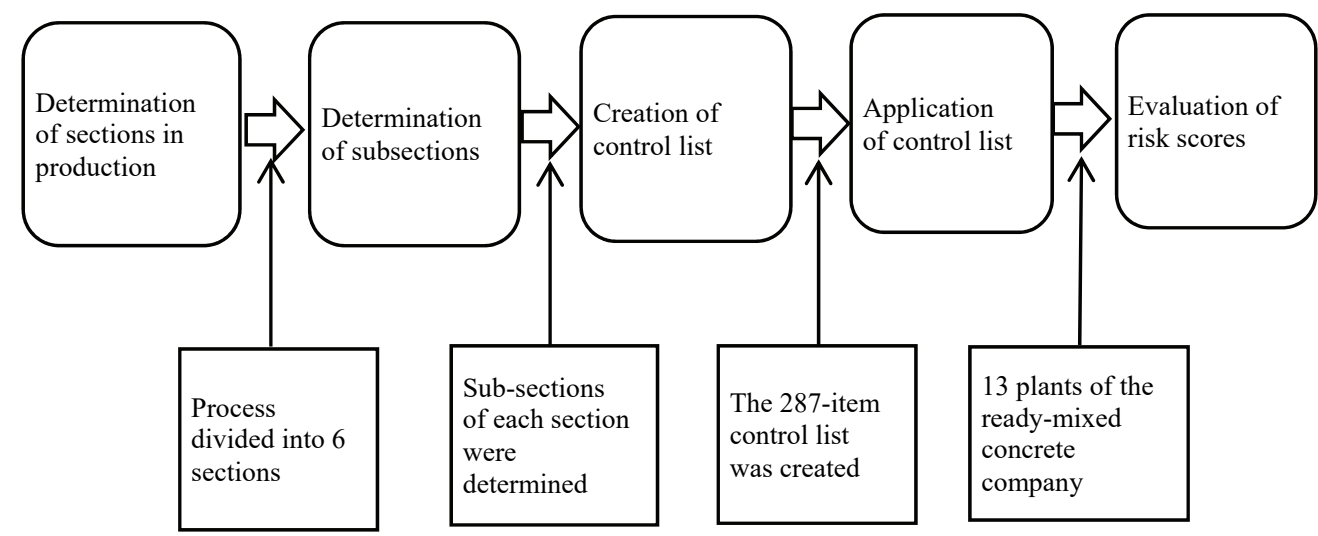

Figure 2 - Flow chart of the methodology

\section{RESULTS}

The plants, analyses performed, were evaluated separately for each section. The first section covers managerial OHS precautions (Table 3). The lack of managerial OHS precautions for almost all visited plants can be listed as OHS policies, reward-penalty systematics, emergency action plan (EAP), first aid instructions, fire extinguishers, OHS policy records, OHS expert, not taking into consideration near-miss reports, and the root cause analysis of previous accidents. Besides these, risk analysis, lockout - tagout system, basic OHS training, a delivery record of personal protective equipment (PPE), and accident and damage reports were mostly missing in plants.

Plant entrance, plant entrance OHS warning sign, on-site traffic plan, and plant lighting were investigated in Section 2(Table 4). The most striking point in this section is that no facility had a plant entrance OHS warning sign. In addition, only two plants had an "on-site traffic plan". Although there were deficiencies in the entrance and lighting parts of the plant, certain precautions had been taken. 
Table 3 - General evaluation.

\begin{tabular}{|c|c|c|c|c|c|c|c|c|c|c|c|c|c|c|c|}
\hline \multirow{2}{*}{$\begin{array}{l}\text { List } \\
\text { No }\end{array}$} & \multirow{2}{*}{ MANAGERIAL OHS PRECAUTIONS } & \multicolumn{14}{|c|}{ PILOTED-TEST } \\
\hline & & NV* & 1 & 2 & 3 & 4 & 5 & 6 & 7 & 8 & 9 & 10 & 11 & 12 & 13 \\
\hline 1 & Is a risk analysis available in terms of OHS? & 9 & - & - & + & - & - & + & - & + & - & + & + & - & - \\
\hline 2 & Does the company possess an approved OHS policy? & 3 & - & - & - & - & - & - & - & - & - & - & - & - & - \\
\hline 3 & Is a reward \& penalty audit systematic available? & 3 & - & - & - & - & - & - & - & - & - & - & - & - & - \\
\hline 4 & Is a lockout tag-out system available? & 9 & - & - & + & + & + & - & - & - & + & - & - & + & + \\
\hline 5 & $\begin{array}{l}\text { Are the general cleaning and maintenance rules } \\
\text { followed? }\end{array}$ & 3 & - & + & + & + & + & + & + & + & + & + & + & + & + \\
\hline 6 & $\begin{array}{l}\text { Is an emergency action plan (EAP) available at the } \\
\text { plant? }\end{array}$ & 9 & - & - & - & - & - & - & - & - & - & - & - & - & - \\
\hline 7 & $\begin{array}{l}\text { Is the list of fire extinguishers and their places hanged } \\
\text { visibly? }\end{array}$ & 9 & - & - & - & - & - & - & - & - & - & - & - & - & - \\
\hline 8 & Is the EAP visibly displayed? & 3 & - & - & - & - & - & - & - & - & - & - & - & - & - \\
\hline 9 & $\begin{array}{l}\text { Are fire, earthquake, flood - with a script drills } \\
\text { performed? }\end{array}$ & 9 & - & - & - & - & - & - & - & - & - & - & + & - & - \\
\hline 10 & $\begin{array}{l}\text { Are first aid instructions prepared? (teams - gathering } \\
\text { points) }\end{array}$ & 9 & - & - & - & - & - & - & - & - & - & - & - & - & - \\
\hline 11 & $\begin{array}{l}\text { Do all employees (incl. Subcontractors) have basic } \\
\text { OHS training? }\end{array}$ & 3 & - & + & + & - & - & - & - & - & - & - & - & + & + \\
\hline 12 & Do all employees (incl. Subcontractors) have PPE? & 9 & - & + & + & + & + & + & + & + & + & + & + & + & + \\
\hline 13 & $\begin{array}{l}\text { Do all employees (incl. Subcontractors) have delivery } \\
\text { record of PPE? }\end{array}$ & 3 & + & + & - & - & - & + & - & + & - & + & + & - & - \\
\hline 14 & $\begin{array}{l}\text { Do all employees (incl. Subcontractors) possess } \\
\text { certificate of no objection from heavy and hazardous } \\
\text { works? }\end{array}$ & 9 & + & + & + & + & + & + & + & + & + & + & + & - & - \\
\hline 15 & $\begin{array}{l}\text { Are periodical health examinations of all employees } \\
\text { (incl. Subcontractors) carried out? (ears \& lungs) }\end{array}$ & 9 & + & - & + & + & + & + & + & + & + & + & + & - & - \\
\hline 16 & $\begin{array}{l}\text { Is the OHS policy written issued to employees? Are } \\
\text { records available? }\end{array}$ & 3 & - & - & - & - & - & - & - & - & - & - & - & - & - \\
\hline 17 & Is a person available, who is responsible for OHS? & 3 & + & - & - & - & - & - & - & - & - & - & - & - & - \\
\hline 18 & $\begin{array}{l}\text { Do employees use their PPE for their own good and } \\
\text { safety at the plant and working sites? }\end{array}$ & 9 & - & - & + & + & + & - & + & + & + & - & - & - & - \\
\hline 19 & Are the accident and damage reports available? & 3 & - & + & - & - & - & + & - & + & + & + & + & - & - \\
\hline 20 & Are near miss reports available? & 3 & - & - & - & - & - & - & - & - & - & - & - & - & - \\
\hline 21 & $\begin{array}{l}\text { Is an adequate organization available for delivering } \\
\text { near-miss reports? }\end{array}$ & 9 & - & - & - & - & - & - & - & - & - & - & - & - & - \\
\hline 22 & $\begin{array}{l}\text { Is a root cause analysis system available and } \\
\text { implemented? }\end{array}$ & 9 & - & - & - & - & - & - & - & - & - & - & - & - & - \\
\hline
\end{tabular}

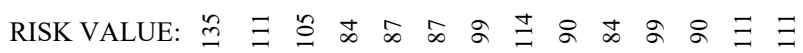

*NV - Numeric Value 
Table 4 - Plant evaluation.

\begin{tabular}{|c|c|c|c|c|c|c|c|c|c|c|c|c|c|c|c|}
\hline \multirow{2}{*}{$\begin{array}{l}\text { List } \\
\text { No }\end{array}$} & \multirow{2}{*}{ PLANT ENTRANCE } & \multicolumn{14}{|c|}{ PILOTED TEST } \\
\hline & & NV & 1 & 2 & 3 & 4 & 5 & 6 & 7 & 8 & 9 & 10 & 11 & 12 & 13 \\
\hline 23 & Is the plant entrance gateavailable? & 9 & + & + & + & + & + & - & - & + & + & + & + & + & + \\
\hline 24 & Is the plant entrance door working in order? & 3 & + & + & + & + & + & - & - & + & + & + & + & - & - \\
\hline 25 & $\begin{array}{l}\text { Is a sign with a logo of the company on it available at the } \\
\text { entrance? }\end{array}$ & 3 & + & + & + & - & - & - & - & + & - & + & + & - & - \\
\hline 26 & Is the sign with company logo appropriately lighted? & 3 & + & + & - & - & - & - & - & - & - & - & - & - & - \\
\hline 27 & Is the sign with company logo appropriately placed? & 3 & + & + & - & - & - & - & - & + & - & + & + & - & - \\
\hline 28 & Are the environmental fence walls available? & 9 & + & + & + & + & + & - & + & + & + & + & + & + & + \\
\hline 29 & $\begin{array}{l}\text { Is the deformation of the environmental fence walls } \\
\text { available? }\end{array}$ & 3 & + & + & + & - & - & - & + & + & + & + & + & - & - \\
\hline 30 & $\begin{array}{l}\text { Is there available parking area for all employees and } \\
\text { visitors? }\end{array}$ & 3 & + & + & - & - & - & - & - & + & + & - & - & - & - \\
\hline 31 & Are channel grates appropriate and clean? & 3 & + & + & + & - & - & - & - & - & + & + & + & - & - \\
\hline \multicolumn{16}{|c|}{ PLANT ENTRANCE OHS WARNING SIGN } \\
\hline 321 & Is it clean? & 3 & - & - & - & - & - & - & - & - & - & - & - & - & - \\
\hline 33 & Is it legible? & 3 & - & - & - & - & - & - & - & - & - & - & - & - & - \\
\hline $34 \mathrm{I}$ & Is it appropriately located? & 3 & - & - & - & - & - & - & - & - & - & - & - & - & - \\
\hline $35 \mathrm{l}$ & Is it appropriately lighted? & 3 & - & - & - & - & - & - & - & - & - & - & - & - & - \\
\hline 361 & Is it generally fit? & 3 & - & - & - & - & - & - & - & - & - & - & - & - & - \\
\hline
\end{tabular}

\begin{tabular}{|c|c|c|c|c|c|c|c|c|c|c|c|c|c|c|c|}
\hline \multicolumn{16}{|c|}{ ON-SITE TRAFFIC PLAN } \\
\hline 37 & Are main rules available? & 9 & - & - & - & - & - & - & - & - & - & - & & + & \\
\hline 38 & Is a traffic plan (vehicle-pedestrian) available? & 3 & - & - & - & - & - & - & - & - & - & - & - & - & \\
\hline 39 & Are on site traffic signs available? & 3 & - & - & - & - & - & - & - & - & - & - & - & + & \\
\hline 40 & Is the plan actively performed? & 9 & - & - & - & - & - & - & - & - & - & - & - & + & \\
\hline 41 & Does loader comply with on-site traffic plan? & 9 & - & - & - & - & - & - & - & - & - & - & & + & \\
\hline 42 & Do aggregate trucks comply with on-site traffic plan? & 9 & - & - & - & - & - & - & - & - & - & - & - & + & \\
\hline 43 & Do cement trailers comply with on-site traffic plan? & 9 & - & - & - & - & - & - & - & - & - & - & - & + & \\
\hline 44 & $\begin{array}{l}\text { Do passenger cars (visitor-company) comply with on-site } \\
\text { traffic plan? }\end{array}$ & 9 & - & - & - & - & - & - & - & - & - & - & & + & \\
\hline 45 & Do truck mixers - pumps comply with on-site traffic plan? & 9 & - & - & - & - & - & - & - & - & - & - & - & + & \\
\hline
\end{tabular}

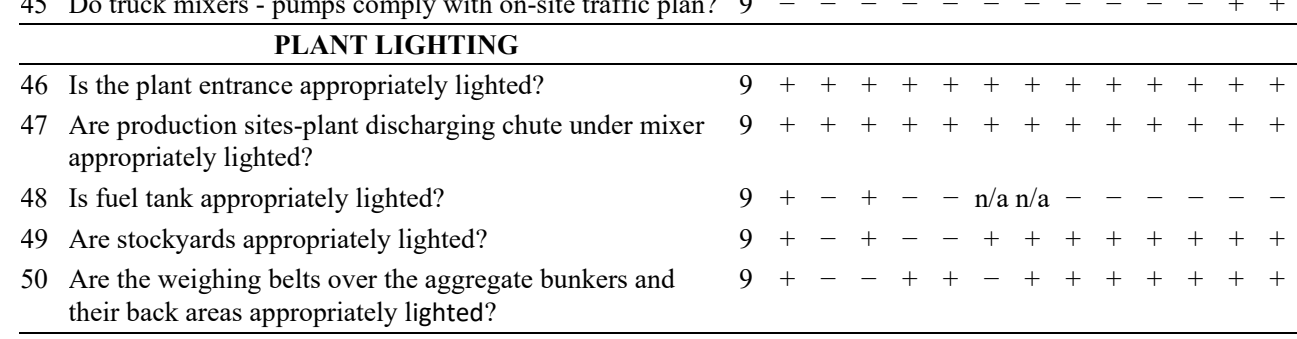

The material storage and production sections are presented in Table 5. Common lack of stockyards was warning signs and indoor stock area. Frame and cover of a manhole, bump concrete in front of the bunker and warning signs of bunker were missing. In general, the 
lack of horizontal conveyors was warning signs, secured surrounding, fire extinguishers, and appropriate walking platforms and their railings. It is quite remarkable that almost in all plants vertical conveyors were not secured and there were no emergency stops. Besides, there were no warning signs. The interlock system of the mixer was not secured against dust and there were no cleaning and maintenance instructions. Common lack of truck mixer loading can be listed as; no loading indicator, no docking stop mechanism, no safe area for the operator. Common lack of cement silo safety was rubber protection under the electric panel, warning signs around the electric panel, rope grab \& d-clip, bottom cap of stairs to the silo, guard chains on silo venting filters, and safety belts and appropriate working platform. The pressure gauge was missing in the silo automation of all plants. There were no warning signs around the cement trailer unloading part and no fixed support (bed) for hose clamps. Commonly, there were no instructions to follow for drivers. In general, like other parts, there were no warning signs around the electric panel of the admixture tank. Commonly, there was no rubber protection below the electric panel, or an emergency instruction, or emergency instruction.

Table 5 - Material storage and production evaluation.

\begin{tabular}{|c|c|c|c|c|c|c|c|c|c|c|c|c|c|c|c|}
\hline \multirow{2}{*}{ No } & \multirow{2}{*}{ STOCKYARD CONFORMITY } & \multicolumn{14}{|c|}{ PILOTED TEST } \\
\hline & & NV & 1 & 2 & 3 & 4 & 5 & 6 & 7 & 8 & 9 & 10 & 11 & 12 & 13 \\
\hline 51 & Are aggregate labelling signs appropriate? & 9 & + & + & + & + & + & - & + & + & + & - & - & - & - \\
\hline 52 & Are closing metal sheets of stockyard appropriate? & 9 & + & + & + & + & + & - & + & + & + & + & + & + & + \\
\hline 53 & Is the stockyard efficiently lighted? & 9 & - & - & + & - & - & + & + & + & + & + & + & + & + \\
\hline 54 & Is the slope of the stockyard acceptable? & 9 & + & + & + & + & + & + & + & + & + & + & + & + & + \\
\hline 55 & $\begin{array}{l}\text { Are the guards on the way from the stockyard to } \\
\text { the bunker suitable? }\end{array}$ & 9 & - & - & - & + & + & - & + & + & + & - & - & + & + \\
\hline 56 & $\begin{array}{l}\text { Is there any warning sing available? (e.g. "no } \\
\text { trespassing") }\end{array}$ & 3 & - & - & - & - & - & - & - & - & - & - & - & + & + \\
\hline 57 & Is the maneuvering area appropriate for the loader? & 9 & + & + & + & + & + & + & + & + & + & + & + & + & + \\
\hline & $\begin{array}{l}\text { Is the working slope of the stockyard appropriate } \\
\text { for loaders and trucks? }\end{array}$ & 9 & + & - & + & + & + & + & + & + & + & - & - & + & + \\
\hline & $\begin{array}{l}\text { Is the dust emission levels at acceptable levels in } \\
\text { the stockyard? }\end{array}$ & 3 & + & + & - & + & + & - & - & - & + & + & + & + & + \\
\hline & Is there an indoor stock area? & 3 & - & - & - & - & - & - & + & + & + & - & - & - & - \\
\hline
\end{tabular}

\begin{tabular}{|c|c|c|c|c|c|c|c|c|c|c|c|c|c|c|}
\hline BUNKER CONFORMITY & & & & & & & & & & & & & & \\
\hline 61 Are there railings around the bunker? & 3 & + & + & - & + & + & + & + & + & + & + & + & - & - \\
\hline 62 Is there frame and cover of manhole of bunker? & 3 & + & - & - & - & - & - & - & - & - & - & - & + & + \\
\hline 63 Are the grate openings of the bunker appropriate? & 9 & + & + & + & + & + & - & + & + & - & - & - & - & - \\
\hline 64 Is an upside closing possible? & 3 & + & + & + & + & + & + & + & + & + & + & + & + & + \\
\hline $\begin{array}{l}65 \text { Is there bump barrier concrete in front of the } \\
\text { bunker? }\end{array}$ & 9 & + & - & - & - & + & - & + & + & - & - & - & + & \\
\hline 66 Are aggregate labelling signs of bunker divisions? & 3 & + & + & + & + & - & - & + & + & + & + & + & + & $T$ \\
\hline 67 Is there any warning sing available? & 9 & - & - & - & - & - & - & - & - & - & - & - & - & \\
\hline 68 Are the bunker efficiently lighted? & 9 & + & - & + & - & + & - & + & + & + & - & - & - & - \\
\hline
\end{tabular}




\section{HORIZONTAL CONVEYORS}

69 Are power outlets protected?

70 Are walking platforms and their railings appropriate?

71 Is the lighting sufficient?

72 Are the warning signs available?

73 Is there cord switch?

74 Is there emergency stop?

75 Is there any platform with railings?

76 Is motor protecting casing available?

77 Is the surrounding area secured?

78 Is the underside of the conveyor regularly cleaned?

79 Are there sufficient appropriately located fire extinguishers?

80 Is the periodic check and filling of the fire extinguishers done?

81 Are there top, side and bottom protections for weighing belts available?

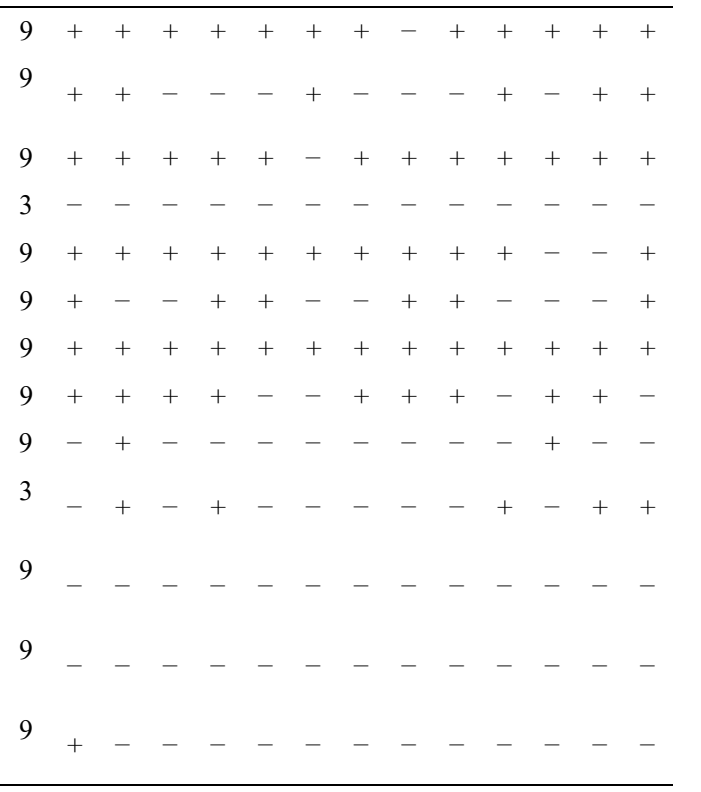

\section{VERTICAL CONVEYORS}

82 Is the walkway available?

83 Is the railing appropriate?

84 Is the protecting upper cover?

85 Is there protection under the conveyor?

86 Are vertical conveyors secured? (chain)

87 Is there motor protecting casing available?

88 Does cord switch work in order?

89 Does emergency stop work in order?

90 Is the lighting sufficient?

91 Are the warning signs?

92 Are walking platform stairs appropriate?

\begin{tabular}{lllllllllllllll}
9 & + & & + & + & + & + & + & + & + & + & + & + & + \\
9 & + & - & + & + & + & + & + & + & - & + & + & + \\
3 & + & + & + & + & + & + & + & + & + & + & + & + \\
3 & + & & - & + & + & - & - & + & + & + & + & + & + \\
3 & - & & + & - & - & - & - & - & + & - & + & - & - \\
9 & - & $n / a$ & + & - & + & + & + & + & + & - & + & - & - \\
9 & - & & + & + & + & + & + & + & + & + & - & + & - \\
9 & - & & - & - & - & - & - & - & - & + & - & - & - \\
9 & + & & + & - & - & + & + & - & + & + & + & - & + \\
3 & - & - & - & - & - & - & - & - & - & - & - & - \\
9 & + & & + & + & - & + & + & + & + & - & + & + & + \\
\hline
\end{tabular}

"HORIZONTAL-VERTICAL CONVEYOR JOINTS
93 Is there protecting upper cover available?

94 Is the surrounding secured?

95 Does cord switch work in order?

96 Does emergency stop work in order?

97 Are there warning signs available?

98 Is it well-organized?

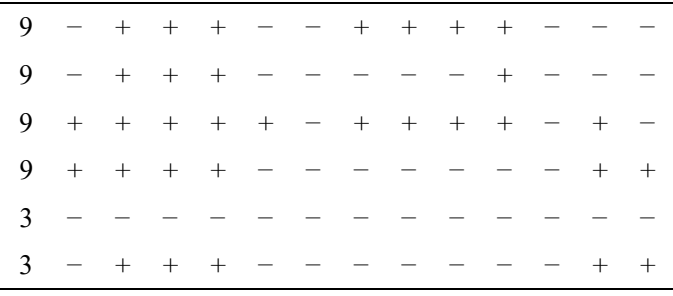

\section{MIXING PROCESS}

99 Are power outlets protected? 
100Does emergency stop of the mixer work in order?

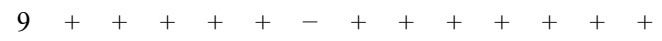

101Are the railing and baseboards of the discharge platform appropriate?

102 Is the interlock system of the mixer appropriate?

103 Is the interlock system of mixer secured against dust?

104Are mixer chains, locked protecting covers of chain gear, switch available?

105Are there cleaning and maintenance instructions for the mixer?

106Are belt and pulley protections appropriate?

\section{TRUCK MIXER LOADING}

107Is there a loading indicator?

108Is there docking stop mechanism?

109Is there a safe area for the operator?

110Are the discharging chute rubbers appropriate?

111 Is the discharging unit sufficiently lighted?

112Are there railings on the stairway to the loading platform?

113Are covering sheets of loading unit appropriate?

114Do the mixer caps leak cement grout?

$+++++++++++$

115Is the loading area ground appropriate?

\section{CEMENT SILO SAFETY}

116Are there electric panel doors available, and in working order?

117Is rubber protection under electric panel available? 9

118Are there warning signs around the electric panel? 9

119Are silo filters working in order?

120Is the maintenance of silo venting filter periodically performed?

121 Are there railing $\&$ baseboard on the upper platform of the silo?

122Is there deck ladder?

123Is there a rope grab \& d-clip?

$\begin{array}{llllllllllllllllllllllll}3 & - & - & - & - & - & - & - & - & - & - & - & - & - \\ 1 & + & - & - & - & - & - & - & - & - & - & - & - & - \\ 3 & - & - & - & - & - & - & - & + & - & - & - & - & - \\ 1 & + & + & - & + & + & + & + & + & + & - & + & + & + \\ 9 & + & + & + & + & + & + & + & + & + & + & + & + & + \\ 9 & + & + & + & + & + & + & + & + & + & - & + & + & + \\ 3 & + & + & + & + & + & + & + & + & + & + & + & + & + \\ 3 & + & - & - & + & + & + & + & - & + & + & + & + & + \\ 9 & - & + & - & - & - & - & + & + & - & - & - & - & -\end{array}$

$9+4+4+-\quad+\quad+\quad+\quad+\quad+\quad+\quad+$

124Are there bottom cap of stairs to silo? Is it actively 9 in order?

125Are there guard chains on silo venting filters?

126Do personnel climbing to the top of the silo have safety belt and is there an appropriate working platform?

127Is there any false loading preventive system?

128Are silos sufficiently lighted? 


\begin{tabular}{|c|c|c|c|c|c|c|c|c|c|c|c|c|c|c|}
\hline SILO AUTOMATION & & & & & & & & & & & & & & \\
\hline 130Are there pressure gauges? & 3 & - & - & - & - & - & - & - & - & - & - & - & - & - \\
\hline 131Does maximum level indicator work in order? & 3 & - & + & + & + & + & - & + & + & - & + & + & + & + \\
\hline 132Does electrical system work in order? & 3 & + & + & + & + & + & + & + & + & + & + & + & + & + \\
\hline 133Is there overflow emergency siren? & 3 & + & + & + & + & + & - & + & - & + & + & + & + & + \\
\hline
\end{tabular}

\section{CEMENT TRAILER UNLOADING}

134Are there warning signs?

135Is fixing support (bed) for hose clamps provided?

136Is there flange lock system?

$3-\quad-\quad-\quad-\quad-\quad-\quad-\quad-\quad-\quad-\quad-\quad-\quad-$

137Is there cement trailer board switch lock available? $9+++++++++-++$

138Is the plug-socket compatibility provided? $\quad 3+++++++++++++++$

139Is cement trailer unloading instructions hang? $3---++++---+_{-}+--$

140Does the driver follow the instructions? $\quad 9---++++-\quad-\quad-\quad-\quad-\quad-\quad-$

\begin{tabular}{|c|c|c|c|c|c|c|c|c|c|c|c|c|c|c|}
\hline \multicolumn{15}{|l|}{ ADMIXTURE TANK } \\
\hline $\begin{array}{l}\text { 141 Are electric panel doors available, working in } \\
\text { order? }\end{array}$ & 9 & + & + & + & + & + & + & + & + & + & + & + & + & + \\
\hline $\begin{array}{l}\text { 142Is rubber protection below electric panel } \\
\text { available? }\end{array}$ & 9 & - & - & - & - & - & - & - & - & - & + & + & - & - \\
\hline 143Are there warning signs around the electric panel? & 3 & - & - & - & - & - & - & - & - & - & - & - & - & - \\
\hline $\begin{array}{l}\text { 144Are there railings on admixture tank stairs and } \\
\text { upper platforms? }\end{array}$ & 9 & + & + & + & + & + & + & - & + & + & + & + & + & + \\
\hline 145Are there admixture labelling signs on the tanks? & 1 & - & - & - & + & + & - & + & - & + & - & - & - & - \\
\hline 146Are the admixture tanks sufficiently lighted? & 9 & + & - & + & - & - & + & - & + & + & - & + & + & + \\
\hline $\begin{array}{l}\text { 147Are empty tanks, barrels etc. kept under control in } \\
\text { a suitable place? }\end{array}$ & 3 & - & - & - & + & - & + & - & + & + & + & - & - & + \\
\hline 148Is there any leak? & 9 & + & + & + & + & + & + & + & - & + & - & + & + & + \\
\hline 149Does the level indicator work? & 1 & + & + & + & + & + & + & + & + & + & + & + & + & + \\
\hline 150Is there an overflow measure? & 9 & + & + & + & + & + & + & + & + & + & + & + & + & - \\
\hline 151 Is the engine under protection? & 9 & + & - & + & + & + & + & + & + & + & + & + & + & + \\
\hline 152Is there an emergency instruction? & 3 & - & - & - & - & - & - & - & - & - & - & - & - & - \\
\hline 153Is the MSDS (material safety data sheet) hanged? & 3 & - & - & - & - & - & - & - & + & - & - & - & - & - \\
\hline
\end{tabular}

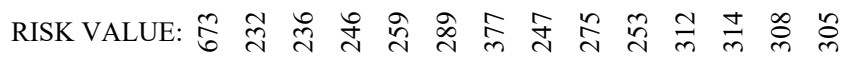

Weighbridge, recycled water reservoir, compressor, water booster, generator, fuel tank, operating room, electrical panels, lighting rod, grounding, and transformer AC panel were investigated in Section 4 (Table 6). In general, there were no protection sets on the weighbridge ramp and the weighbridge itself. Cleaning records and instructions of the recycled water reservoir were missing. Shield grid over the reservoir and lighting was missing and chain hoists of the submersible pumps were inappropriate mostly. In general, 
maintenance and operation instruction of compressors and warning signs were not hanged. There was no rubber protection under the electrical panel and the compressor room was not sufficiently lighted. In general, the lack of water booster can be listed as, warning signs around the electrical panel, signs of booster tank room, operation and maintenance instruction and rubber protection under the electrical panel. General physical precautions of the generator were not taken in most of the plants. In addition, operation instruction of the generator was not hanged, generator maintenance reports were missing, and lighting was poor. The antistatic precaution was not available in any of the plants. Although there were deficiencies in the operating room and electrical panels, rubber protections and warning signs were missing.

Table 6 - Auxiliary facility evaluation.

\begin{tabular}{lclllllllllllll}
\hline \multirow{2}{*}{ No } & \multicolumn{1}{c}{ PEIGHBRIDGE } & \multicolumn{1}{c}{ PILOTED TEST } \\
\cline { 3 - 11 } & NV & $\mathbf{1}$ & $\mathbf{2}$ & $\mathbf{3}$ & $\mathbf{4}$ & $\mathbf{5}$ & $\mathbf{6}$ & $\mathbf{7}$ & $\mathbf{8}$ & $\mathbf{9}$ & $\mathbf{1 0}$ & $\mathbf{1 1}$ & $\mathbf{1 2}$ & $\mathbf{1 3}$ \\
\hline 154Are there protection sets on weighbridge ramp? & 9 & - & - & - & - & - & - & - & - & - & - & - & - & - \\
155Are there protection sets on weighbridge? & 9 & - & - & - & - & - & - & - & - & - & - & - & - & - \\
156Are weighbridge bolts controlled periodically? & 3 & + & + & + & + & + & - & - & + & + & - & - & - & - \\
157Is weighbridge lighted sufficiently? & 9 & + & + & - & + & + & + & - & + & + & + & + & + \\
\hline
\end{tabular}

\section{RECYCLED WATER RESERVOIR}

158Is there a railing?

159Is there shield grid over the reservoir?

160Is it lighted?

161Is the motor secured?

162 Are there warning signs? (reservoir depths - no
walk around, etc.)

$\begin{array}{llllllllllllll}9 & - & + & + & - & - & - & + & + & - & + & + & - & - \\ 9 & + & - & + & - & - & - & - & + & + & - & - & - & - \\ 9 & + & - & - & - & - & - & - & + & - & - & - & + & + \\ 9 & + & + & + & + & + & - & + & + & + & + & + & + & +\end{array}$

163 Are electric panel doors available, and in working
order? 9 64Is rubber protection under electric panel available? 165Is the capacity of the reservoir sufficient? 166Is there cleaning instruction of the reservoir? 167Are there cleaning records of reservoirs?

${ }_{168}$ Are the chain hoists of the submersible pumps appropriate?

\section{COMPRESSOR}

169Are general physical precautions taken? (securing the surrounding of closed area - materials storage)

170Are compressor belt protection, air tank safety valve, manometer appropriate?

171 Is the hydrostatic test report up to date?

172Is the maintenance and operation instruction hanged?

173Are the warning signs hanged? (ear protection, only 3 authorized person) 
174Is there electrical panel covers, does it work in order?

175Is there rubber protection below the electrical panel?

176Is the compressor room sufficiently lighted?

\section{WATER BOOSTER}

177Are there electrical panel covers, doethey work in order?

178Is there rubber protection under the electrical panel? $9--_{-}--_{-}-+_{-}++_{-}-$

179Is the booster tank room sufficiently lighted?

180Are there warning signs around electrical panel?

$9++++++++++++$

181 Are the signs of booster tank room sufficient?

182Is the operation and maintenance instruction of booster tank available?

183Are the water booster and pressured tanks in a closed room?

184Are the physical conditions of the booster and pressured tanks room appropriate?

185Are the fan of the motor and coupling protections appropriate?

\section{GENERATOR}

186Are general physical precautions taken? (securing 3 the surrounding of closed area)

187Is the operation instruction of the generator hanged? 3

188Is there a leak or overflow in the generator fuel tank?

189Is the periodic maintenance of fire extinguishers appropriate?

190Are warning signs hanged? (danger; do not touch the generator; only authorized person, etc.)

191Are there generator maintenance reports?

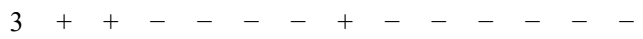

192Is the generator sufficiently lighted?

\section{FUEL TANK}

193Is there a set to prevent vehicles from crashing into the fuel tank?

194Are warning signs available?

195Are operating instructions available'?

196Is a fire extinguisher available?

197Is there antistatic precaution?

198Is there a fuel tank ventilation does it work in order?

199Is the tank sufficiently lighted?

200Is there a locking mechanism for the fuel tank and the pump, does it work in order? 


\section{OPERATING ROOM}

201 Is there emergency stop switch-marking (on-off)
system?

9

202 Is there fire extinguisher ( $30 \mathrm{~cm}$ high; fixed; not

9

depleted)

203Is there an air conditionerunit?

204Is everything well organized? 205 Is there electrical panel covers, does it work in
order?

206Is there rubber protection under the electrical panel? 9

207Are there warning signs around the electrical panel? 3

208Are electrical panel keys available?

$9+++++-++++-+$

209Is the operating room sufficiently lighted?

$9++\quad+\quad+\quad+\quad+\quad+\quad+\quad+\quad+$

\section{ELECTRICAL PANELS}

210Is grounding available?

211Are the panel doors closed?

212 Are they locked and do only authorized personnel have the keys?

213Is there rubber band?

214 Are warning signs hanged? (50v, danger, only

$9++\quad+\quad+\quad+\quad+\quad+\quad+\quad+\quad+\quad+$

$215^{\text {Are the physical conditions (height, appearance, }}$

9

215 etc.) appropriate?

\section{LIGHTNING ROD, GROUNDING,}

TRANSFORMER AC PANEL

216Are lightning rod annual maintenance reports available?

217Is there facility grounding?

218Is the facility transformer mast safety lock available?

219Is the transformer maintained (oil change)?

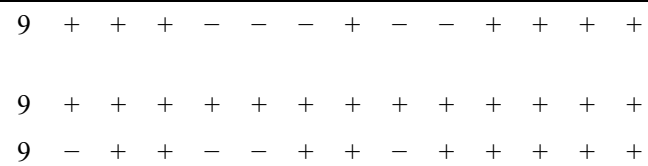

220Are UPS units available? Does they work in order? Is their capacity sufficient?

221Are the doors of transformer and ac panel locked?

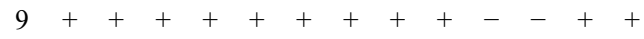

222Is the transformer and ac panel suitable for internal, 9 external lighting?

223Is the transformer and ac panel high enough from the ground?

224Is there any deformation in the transformer and ac panel?

225Is there a rubber band in front of the transformer and ac panel? 
226Are the warning signs in the transformer and ac panel sufficient?

227Is there enough fire extinguisher in transformer? Are they appropriately located?

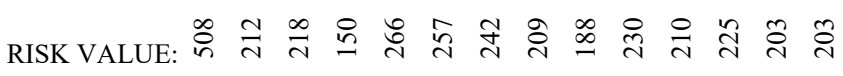

Precautions taken regarding mobile equipment were more extensive than those of other sections (Table 7). The common missing in all plants was the lack of fire extinguisher. Except for this, the truck mixers, pumps, and loaders were generally safe.

Table 7 - Mobil equipment evaluation.

\begin{tabular}{|c|c|c|c|c|c|c|c|c|c|c|c|c|c|c|c|c|}
\hline \multirow{2}{*}{ TRUCK MIXERS } & \multicolumn{16}{|c|}{ PILOTED TEST } \\
\hline & $\mathrm{NV}$ & & 2 & 3 & 4 & 5 & 6 & 7 & & 8 & 9 & & & 111 & 12 & 13 \\
\hline 228Is there a vehicle tracking system on truck mixers? & 3 & + & + & + & + & 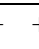 & + & + & & + & + & & + & + & + & + \\
\hline 229Does audible reversing device work properly? & 9 & - & + & + & + & - & + & - & & + & + & & - & - & + & + \\
\hline 230Is there protection on upper platform of the ladder? & 9 & + & + & + & + & - & + & + & & + & + & & + & + & + & + \\
\hline 231Do the backlights of the truck mixers work in order? & 9 & + & + & + & + & - & + & + & & + & + & & - & - & + & + \\
\hline 232Is the ladder to driving cabin appropriate? & 9 & + & + & + & + & - & + & + & & + & + & & + & + & + & + \\
\hline 233Is there side protection of discharge gutters? & 9 & + & + & + & + & - & + & + & & + & + & & + & + & + & + \\
\hline $\begin{array}{l}\text { 234Is there any mechanism on truck mixers to prevent } \\
\text { overflow of concrete? }\end{array}$ & 3 & - & - & + & + & - & + & - & & + & + & & - & - & + & + \\
\hline 235Are the headlights and taillights in working order? & 9 & + & + & + & + & + & + & + & & + & + & & + & + & + & + \\
\hline 236Are the fire extinguishers available? & 9 & - & - & + & - & - & - & + & $\mathrm{n} / \mathrm{a}$ & - & - & & + & + & - & - \\
\hline 237Is the rest of components of drive cab fixed inside? & 3 & - & - & + & + & - & + & + & & - & + & & + & + & + & + \\
\hline 238Are they periodically serviced? & 9 & - & - & + & + & - & + & + & & + & + & & + & + & + & + \\
\hline 239Are there firs aid kits in every truck mixer? & 9 & + & + & + & + & - & + & - & & + & + & & + & + & + & + \\
\hline 240Do tachometers work in order? & 3 & + & + & + & + & - & + & + & & + & + & & + & + & + & + \\
\hline 241Do truck mixer drivers have operating license? & 3 & + & - & + & + & - & + & + & & + & + & & + & + & - & - \\
\hline 242Do truck mixer drivers have psycho-technical report? & 9 & + & + & + & + & -1 & + & + & & + & + & & + & + & + & + \\
\hline 243Did truck mixer drivers have orientation training? & 3 & - & - & + & + & - & + & + & & - & + & & - & - & + & + \\
\hline 244Are the headlights of working truck mixers on?? & 9 & + & - & + & - & - & - & - & & + & - & & - & - & + & + \\
\hline
\end{tabular}

\section{PUMPS}

245Is there a vehicle tracking system on pumps?

246 Is there any automatic system on pumps against

rollover?

247Does the audible reversing device work properly?

248Do the backlights of the pumps work properly?

249Is there grate on hoppers?

250Are pumps periodically maintained?

251Is the ladder to platform appropriate?

\begin{tabular}{|c|c|c|c|c|c|c|c|c|c|c|c|c|c|}
\hline 3 & + & + & + & + & + & + & & + & + & - & - & + & + \\
\hline 9 & + & + & + & + & + & + & & + & + & + & + & + & + \\
\hline 9 & - & + & + & + & + & - & & + & + & - & - & - & - \\
\hline 9 & - & + & + & + & + & - & $\mathrm{n} / \mathrm{a}$ & + & - & - & - & + & + \\
\hline 9 & + & + & + & + & + & + & & + & + & + & + & + & + \\
\hline 9 & - & - & + & + & + & + & & + & + & + & + & + & + \\
\hline 9 & - & + & + & + & + & + & & + & + & + & + & + & + \\
\hline
\end{tabular}


252Are there end hose safety straps?

253Are headlights and stoplights working in order?

254Is the ladder to drive cab appropriate?

255Are there bump stop outriggers?

256Are the fire extinguishers appropriate?

257Is the rest of components of drive cab fixed inside?

258Are there traffic cones available?

259Do tachometers of pumps work in order?

260Do operators have operating certificates?

261 Do pump operators have parachute type safety
harness?

262Do pump operators have psycho-technical report?

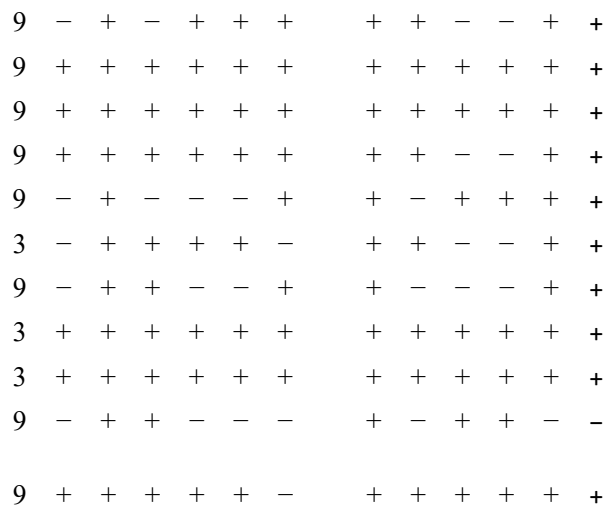

\begin{tabular}{|c|c|c|c|c|c|c|c|c|c|c|c|c|c|c|}
\hline LOADER CONFORMITY & & & & & & & & & & & & & & \\
\hline 263Does operator have G class driving license? & 9 & + & - & + & + & + & + & + & + & + & + & + & + & + \\
\hline 264Does operator have heavy equipment certificate? & 9 & - & + & + & + & + & + & $\mathrm{n} / \mathrm{a}$ & + & + & + & + & - & - \\
\hline 265Does reversing warning lamp work properly? & 9 & - & - & + & + & + & + & + & + & + & + & + & + & + \\
\hline 266Does audible reversing device work properly? & 9 & + & + & + & + & + & + & + & + & + & + & + & + & + \\
\hline 267Are headlights-mirrors and glasses appropriate? & 9 & + & + & + & + & + & - & + & + & + & + & + & + & + \\
\hline 268Is there a seatbelt? & 9 & + & + & + & + & + & - & + & + & + & + & + & + & + \\
\hline 269Do loader operators have operator license? & 3 & - & + & - & + & + & - & + & + & + & - & - & - & - \\
\hline $\begin{array}{l}270 \text { Are there periodic maintenance instructions? Are they } \\
\text { followed? }\end{array}$ & 9 & - & - & + & + & + & - & + & + & + & + & + & - & - \\
\hline 271Are loader fire extinguishers appropriate? & 9 & - & - & - & - & - & - & - & - & - & - & - & - & - \\
\hline $\begin{array}{r}\text { RISK } \\
\text { VALUE }\end{array}$ & $\stackrel{\circ}{m}$ & $\stackrel{\circ}{n}$ & $\tilde{a}$ & $\stackrel{?}{m}$ & $\stackrel{n}{q}$ & $\stackrel{n}{q}$ & $\stackrel{\infty}{\varrho}$ & I & $\stackrel{む}{さ}$ & $\tilde{\sigma}$ & ๙ุ & ๙ั & ஒ & 유 \\
\hline
\end{tabular}

According to laboratory evaluation (Table 8) common missing precautions were precaution against electric shock in the cure pools, precaution against the slippery ground, precaution against free fall of concrete specimens, warning signs, instructions, and labeling, specimen tong.

Table 8 - Laboratory evaluation.

\begin{tabular}{|c|c|c|c|c|c|c|c|c|c|c|c|c|c|c|}
\hline \multirow{2}{*}{ 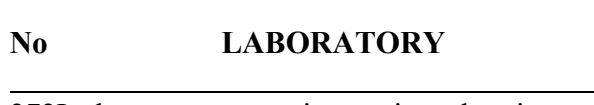 } & \multicolumn{14}{|c|}{ PILOTED TEST } \\
\hline & NV & 1 & 2 & 3 & 4 & 5 & 6 & 7 & 8 & 9 & 10 & 11 & 12 & 13 \\
\hline $\begin{array}{l}\text { 272Is there any precaution against electric } \\
\text { shock in cure pools? }\end{array}$ & 9 & - & - & - & - & - & - & - & - & - & + & + & - & - \\
\hline 273Is there a system to cover the curing pool? & 3 & - & + & + & - & - & - & - & + & - & + & + & - & - \\
\hline $\begin{array}{l}\text { 274Is there any precaution against slippery } \\
\text { ground? }\end{array}$ & 9 & - & - & - & - & - & - & - & - & - & - & - & - & - \\
\hline $\begin{array}{l}\text { 275Is there any precaution against free fall of } \\
\text { concrete specimens? }\end{array}$ & 9 & - & - & + & - & - & - & + & - & - & - & - & & + \\
\hline
\end{tabular}


276Are there warning signs, instructions, and labeling?

277Is there any tool to carry specimens from the curing pool to test machine?

278Is there protective cap-door-cover in front of the test machine?

279Is there warning sign on the test machine such as "only authorized persons"?

280Is pneumatic specimen demolding system secured?

281Are there appropriate PPE in the laboratory? (glove, glasses, mask, etc.)

282Are there specimen tongs in the laboratory? $9----_{-}--_{-}-{ }_{-}-$ 283Is the drying oven instruction appropriate? $3--_{-}--_{-}--_{+}+++$ 284Is there a protective glove for drying oven? $9---_{-}--_{-}--_{-}$ 285Is there a kit/tool at the end of pneumatic specimen demolding hose?

286Are there enough fire extinguishers? Are they appropriately located?

287Is periodic maintenance of fire extinguishers properly performed?
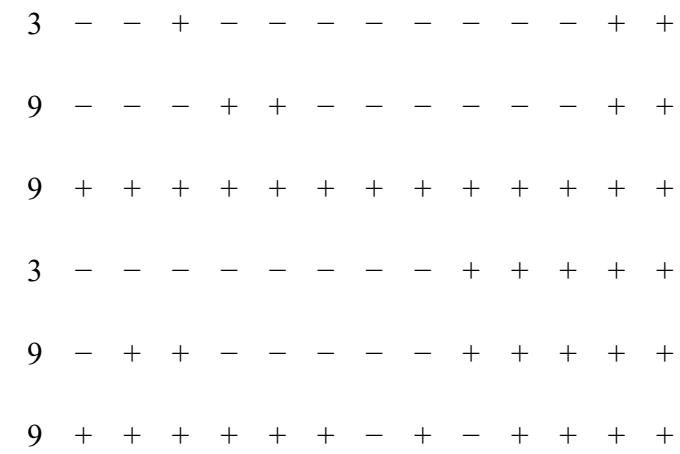

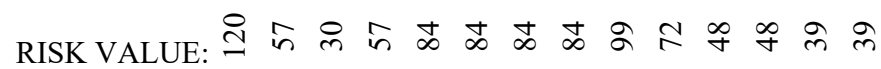

Table 9 - Risk values of visited plants.

\begin{tabular}{|c|c|c|c|c|c|c|c|c|c|c|c|c|c|c|c|}
\hline \multirow{2}{*}{$\begin{array}{l}\text { List } \\
\text { No }\end{array}$} & \multirow{2}{*}{ Section } & \multirow{2}{*}{$\begin{array}{c}\text { Total RV } \\
\text { of } \\
\text { Sections }\end{array}$} & \multicolumn{13}{|c|}{ Risk Values of Visited Plants } \\
\hline & & & 1 & 2 & 3 & 4 & 5 & 6 & 7 & 8 & 9 & 10 & 11 & 12 & 13 \\
\hline $1-22$ & General & 135 & 111 & 105 & 84 & 87 & 87 & 99 & 114 & 90 & 84 & 99 & 90 & 111 & 111 \\
\hline $\begin{array}{l}23- \\
50\end{array}$ & Plant & 168 & 84 & 111 & 102 & 120 & 120 & 132 & 111 & 99 & 102 & 99 & 99 & 66 & 66 \\
\hline $\begin{array}{l}51- \\
153\end{array}$ & $\begin{array}{l}\text { Mat. storage } \\
\text { and pro. }\end{array}$ & 673 & 232 & 236 & 246 & 259 & 289 & 377 & 247 & 275 & 253 & 312 & 314 & 308 & 305 \\
\hline $\begin{array}{l}154- \\
227\end{array}$ & $\begin{array}{l}\text { Auxiliary } \\
\text { facility }\end{array}$ & 508 & 212 & 218 & 150 & 266 & 257 & 242 & 209 & 188 & 230 & 210 & 225 & 203 & 203 \\
\hline $\begin{array}{l}228- \\
271\end{array}$ & $\begin{array}{l}\text { Mobil } \\
\text { equipment }\end{array}$ & 330 & 150 & 93 & 30 & 45 & 45 & 108 & - & 24 & 63 & 96 & 96 & 60 & 60 \\
\hline $\begin{array}{l}272- \\
287\end{array}$ & Laboratory & 120 & 57 & 30 & 57 & 84 & 84 & 84 & 84 & 99 & 72 & 48 & 48 & 39 & 39 \\
\hline & Total & 1934 & 846 & 793 & 669 & 861 & 882 & 1042 & 765 & 775 & 804 & 864 & 872 & 787 & 784 \\
\hline & $\%$ & & 43.74 & 41.00 & 34.59 & 44.52 & 45.60 & 53.88 & 47.69 & 40.07 & 41.57 & 44.67 & 45.09 & 40.69 & 40.54 \\
\hline
\end{tabular}

The sum of the deficiencies of each plant in all sections for an overall assessment is presented in Table 9. According to the risk values for 13 plants, belonging to one company, the 
deficiencies vary between $53.88 \%$ to 34.59 . This is a good example of the fact that even the same company cannot ensure stability in terms of OHS among its plants.

\section{DISCUSSION AND CONCLUSION}

The ready mixed concrete industry, commonly operating not only in Turkey but also in other countries, needs to be inspected in terms of occupational health and safety because academic studies on this subject are not abundant. This study aimed to develop a control list to be used within the scope of an internal safety evaluation program that can be used by all producers to understand and improve OHS performance in the production process. For this reason, we examined what should be considered for detailed ISEP of the production area of a ready mixed concrete plant and the 287 -item control list was created. Since each safety risk was digitizing in the control list, the maximum risk score of each section was determined. Afterward, the control list thus created was applied in 13 ready mixed concrete plants of a single company. RMC companies need to benefit from a guideline when conducting their own internal evaluations to improve their occupational safety efforts and to make all their plants uniformly safe. In this respect, the study is a reliable guide for RMC manufacturers. Also, it is important to list the common deficiencies of the plants visited as follows.

- $\quad$ Risk analysis was missing in most of the visited plants. Besides, none of the plants had an approved OHS policy. The ready mixed concrete industry is one of the subsectors of construction that has many risks as described above. It follows that risk assessment is very important for any ready mixed concrete plant. Carrying out these assessments is the only way of ensuring that the chances of incidents occurring are reduced as much as possible, and everyone is kept safe.

- The emergency action plan was not available in any of the plants. A workplace emergency is any unforeseen situation that threatens employees, customers, or the public; disrupts or shuts down operations; or causes physical or environmental damage [50]. The purpose of an EAP is to facilitate and organize employer and employee actions during workplace emergencies [51]. Therefore, it is crucial to have EAP in plants and visibly displayed.

- OHS training was mostly missing in the plants. Sawacha et al. (1999) stated that a lack of safety training is one of the causes of accidents [52]. Researchers also indicated that safety training is the most important safety management practice in terms of safety performance components [53-55]. Adopting safety-training programs increase the awareness of workers on the subject, thereby allowing them to work safely. Therefore, producers should organize and record regular OHS training. Besides, it should be noted that keeping training up to date is just as important as taking it the first time.

- Collecting statistics on safety activities will allow a company to identify common injuries and areas that may be missing in their safety program. OSHA states that collecting near-miss reports helps to create a culture that seeks to identify and control hazards, which will reduce risks and the potential for harm [56]. In addition, reporting near miss incidents can significantly improve worker safety and enhance an organization's safety culture [57]. Near-miss reports were not available in the 
visited plants. Therefore, to understand better the weaknesses in the system that resulted in the circumstances that led to the near miss, root cause analyses could not be conducted. Near miss forms to collect relevant incident data during an investigation and to learn lessons, review controls and implement change where required should be used.

- Surprisingly, no facility had a plant entrance OHS warning sign. OHS warning signs should be made mandatory at the entrance of the plant. This warning sign should symbolize the summary rules that must be observed when entering the plant (Speed limit, helmet use, etc.). Warning signs also were missing in many parts of the production process such as stockyard, bunker, horizontal conveyors, vertical conveyors, horizontal-vertical conveyor joints, cement silo, cement trailer unloading, admixture tank, compressor, generator, operating room, electrical panels. Safety signs play a large part in keeping facilities compliant and employees knowledgeable. It is critical for workers to understand the types of hazards in the workplace, the level of risk the hazard presents, and what precautions to take [58].

- Instructions mean outline or text of technical procedures. Instructions also tell someone how to do something or in which order to do something. First aid instructions, cleaning, and maintenance instructions of the mixer, emergency instruction of admixture tank, cleaning instruction of the reservoir, operation and maintenance instruction of booster tank, operating instruction of fuel tank were missing. These instructions should be prepared by the managers and actively used by workers to prevent them from potential accidents because of the described risks.

- Moving vehicles and equipment on manufacturing sites can be fatal for humans if not used correctly and safely. The layout and traffic flow of a workplace is important for keeping people and plant safe as they move around [59]. Only two plants had an "on-site traffic plan" among the visited plants. Related plans should be prepared and actively used in all RMC plants.

To sum up, risk may remain within acceptable limits within an organization to maintain OHS management applications by using an internal safety evaluation program. The risks described cannot be totally avoided, but the choice can be made so that the risk is minimized. This study is mainly concerned with the assessment of pure risk in ready mixed concrete production, where managers need to know how much risk is involved in the process to decide how to go about it. It is expected that the control list would be an effective tool of preventing and minimizing accidents of RMC industry.

In addition, the control list created within the scope of the internal safety evaluation program includes the legal obligations in the laws and standards in force. According to the risk scores obtained from the control list, it is observed that some of the measures described in the Occupational Safety Law No. 6331 of Turkey and accompanying standards were not in force at the facilities visited. For this reason, ready-mixed concrete producers will also fulfill their legal obligations in the improvement works they will make with reference to this control list.

The created control list is a guide for ready-mixed concrete companies to make their own preliminary assessments and due diligence to reach internationally accepted standards and regulations. Considering the provisions of the ISO 45001 Occupational Health and Safety Management System Standard, the created control list will be able to guide companies, 
especially in Section 6.1 (Methods of identifying risks and opportunities) and Section 6.2 (OHS targets and planning to achieve them).

The employees of the ready mixed concrete industry also experience the risks that may cause occupational diseases such as noise (hearing loss), dust (respiratory system diseases), ergonomics (musculoskeletal system disorders) and so on. However, the control list presented in the study does not cover occupational diseases. In future studies, the subject can also be addressed from this aspect.

\section{Abbreviations}

ACPA - American Concrete Pumping Association

EAP - Emergency Action Plan

ISEP - Internal Safety Evaluation Program

NSCSA - National Ready Mixed Concrete Association

$\mathrm{NV}$ - Numeric Value

OHS - Occupational Health and Safety

OSHA - Occupational Safety and Health Administration

PPE - Personal Protective Equipment

RMC - Ready Mixed Concrete

RV - Risk Value

SMS - Safety Management System

\section{References}

[1] Unsar, S., Sut, N., General assessment of the occupational accidents that occurred in Turkey between the years 2000 and 2005. Saf Sci. 47:614-619, 2009.

[2] Hinze, J.W., Construction Safety. New Jersey: Prentice Hall Publications; 1997.

[3] Ringen, K., Seegal, J., Safety and health in construction industry. Annu Rev Public Health.16:165-188, 1995.

[4] Lim, S., Oh, A., Won, J., Chon, J., Improvement of inspection system for reduction of small-scale construction site accident in Korea. Ind Health. 56:466-474, 2018

[5] Cameron, I., Hare, B., Davies, R., Fatal and major construction accidents: a comparison between Scotland and the rest of Great Britain. Saf Sci. 46:692-708, 2008.

[6] Ale, B.J.M., Bellamy, L.J., Baksteen, H., et al., Accidents in the construction industry in the Netherlands: An analysis of accident reports using Storybuilder. Reliability Eng Syst Saf. 93:1523-1533, 2008. 
[7] Arquillos, A.L., Romero, J.C.R., Gibb, A., Analysis of construction accidents in Spain, 2003-2008. J Saf Res. 43:381-388, 2012.

[8] Colak, B., Etiler, N., Bicer, U., Fatal occupational injuries in the construction sector in Kocaeli, Turkey, 1990-2001. Ind Health. 42:424-430, 2004.

[9] Kartam, N.A., Flood, I., Koushki, P., Construction safety in Kuwait: issues, procedures, problems, and recommendations. Saf Sci. 36:163-184, 2000.

[10] El-Mashaleh, M.S., Al-Smadi, B.M., Hyari, K.H., et al., Safety management in the Jordanian construction industry. Jordan J Civ Eng. 4(1):47-54, 2010.

[11] Chong, H.Y., Low, T.S., Accidents in Malaysian Construction industry: statistical data and court cases. In J Occup Saf Ergon. 20(3):503-513, 2014.

[12] ElSafty, A., ElSafty, A., Malek, M., Construction safety and occupational health education in Egypt, the EU, and US Firms. Open J Civ Eng. 2:174-182, 2012.

[13] Mohammed, Y.D., Ishak, M.B., Study of fatal and non-fatal accidents in construction sector. Malaysian J Civ Eng. 25(1):106-118, 2013.

[14] Halder, D., Rahman, F., Hossain, M., et al., Contributing factors affecting the safety in construction sites of Bangladesh. Proceedings of the International Conference on Advances in Civil, Structural and Mechanical Engineering - ACSM; 2015 Feb 21-22; Bangkok, Thailand. New York (USA): Institute of Research Engineers and Doktors; 2015.

[15] Fabiano, B., Parentini, I., Ferraiolo, A., et al., A Century of accidents in the Italian industry: Relationship with the production cycle. Saf Sci. 2:65-74, 1995.

[16] Tam, C.M., Zeng, S.X., Deng, Z.M., Identifying elements of poor construction safety management in China. Saf Sci. 42:569-586, 2004.

[17] Jannadi, O.A., Bu-Khamsin, M.S., Safety factors considered by industrial contractors in Saudi Arabia. Build Environ. 37(5):539-547, 2002.

[18] Gürcanlı, G.E., Müngen, U., Analysis of Construction Accidents in Turkey and Responsible Parties. Ind Health. 51:581-595, 2013.

[19] Tözer, K.D., Çelik, T., Gürcanlı, G.E., Classification of Construction Accidents in Northern Part of Cyprus. Teknik Dergi. 29(2): 8295-8316, 2018.

[20] Bilir, S., Gürcanlı, G.E., A Method for Determination of Accident Probability in Construction Industry. Teknik Dergi, 29(4): 8537-8561, 2018.

[21] Baradan, S., Akboğa, Ö., Çetinkaya, U., Usmen, M.A., Ege Bölgesindeki İnşaat İş Kazalarının Sıklık ve Çapraz Tablolama Analizleri. Teknik Dergi. 27(1): 7345-7370, 2016.

[22] Akboğa Kale, Ö., Baradan, S., Identifying Factors that Contribute to Severity of Construction Injuries using Logistic Regression Model. Teknik Dergi. 31(2): 99199940, 2020. 
[23] Aksorn, T., Hadikusumo, B.H.W., The unsafe acts and the decision-to-err factors of Thai construction workers. J Constr in Developing Ctries. 12(1):1-25, 2007.

[24] Ore, T., Stout, N., Traumatic occupational fatalities in the US and Australian construction industries. Am J Ind Med. 30:202-206, 1996.

[25] Pollack, E.S., Griffin, M., Ringen, K., et al., Fatalities in the construction industry in the United States, 1992 and 1993. A J Ind Med. 30:325-330, 1996.

[26] Center for Disease Control and Prevention. Fatal occupational injuries-United States, 1980-97. Morb Mortal Wkly Rep. 50:317-320, 2001.

[27] Rodsari, B.S., Ghodsi, M., Occupational injuries in Tehran. Inj. 36:33-39, 2005.

[28] Tricco, A.C., Colantonio, A., Chipman, M., et al., Work-Related deaths and traumatic brain injury. Brain Inj. 20:719-724, 2006.

[29] Hallowell, M.R., Safety-knowledge management in American construction organizations. J Manag Eng. 28(2):203-211, 2012.

[30] Larsson, T.J., Field, B., The distribution of occupational injuries risks in the Victorian construction industry. Saf Sci. 40:439-456, 2002.

[31] Quora [Internet]: What are the advantages of ready mi concrete?; [cited 2019 Nov 3] Available from: https://www.quora.com/What-are-the-advantages-of-ready-mixconcrete

[32] Turkish Ready Mixed Concrete Association [Internet]: Statistics; [cited 2019 Nov 7] Available from: https://www.thbb.org/en/industry/statistics/

[33] Aichouni, M., On the Use of the Basic Quality Tools for the Improvement of the Construction Industry: A Case Study of a Ready Mixed Concrete Production Process. Int J Civ Environ Eng. 12(5):31-38, 2012.

[34] Sarkar, D., Bhattacharjee, B., Design and application of multivariate CUSUM for quality monitoring of ready mixed concrete. Int J Qual Eng Technol. 4(2):161-179, 2014.

[35] Naso, D., Surico, M., Turchiano, B., et al., Genetic algorithms for supply-chain scheduling: A case study in the distribution od ready mix concrete. Eur J Operational Res. 117:2069-2099, 2007.

[36] Yan, S., Lai, W., An optimal scheduling model for ready mixed concrete supply with overtime considerations. Autom Constr. 16:734-744, 2007.

[37] Sealey, B.J., Phillips, P.S., Hill, G.J., Waste management issues for the UK readymixed concrete industry. Resour Conservation Recycling. 32:321-331, 2001.

[38] Sandrolini, F., Franzoni, E., Waste wash water recycling in ready mixed concrete plants. Cement Concr Res. 31:485-489, 2001.

[39] Schmid, V., Doerner, K.F., Hartl, R.F., et al., Hybridization of very large neighborhood search for ready-mixed concrete delivery problems. Computers\&Operations Res. $37: 559-574,2010$. 
[40] Graham, L.D., Forbes, D.R., Smith, S.D., Modeling the ready mixed concrete delivery system with neural networks. Autom Constr. 15:656-663, 2006.

[41] Akboğa, Ö., Baradan, S., Safety in ready mixed concrete industry: descriptive analysis of injuries and development of preventive measures. Ind Health. 55:1-13, 2017.

[42] Occupational Safety and Health Administration [Internet]: Workers Safety Series Concrete Manufacturing; [cited 2019 Nov 12]. Available from: https://www.osha.gov/Publications/concrete_manufacturing.html

[43] American Concrete Pumping Association [Internet]: Ready Mixed Safety Manual-A guide for the prevention of accidents when delivering to concrete pumps; [cited 2019 Nov 1] Available from: https:/www.concretepumpers.com/sites/concretepumpers.com/files/attachments/read ymixed_safety_manual_v1.0.3_eng_rs.pdf

[44] National Ready Mixed Concrete Association [Internet]: 2017 Presidents Report [cited 2019 Oct 20] Available from: https://www.nrmca.org/downloads/Presidents_Report2017.pdf

[45] OmniSMS [Internet]: Safety Management System, Internal Evaluation Program; [cited 2019 Nov 25]. Available from: https://omnisms.aero/wpcontent/uploads/2018/04/Omni-Aviation-SMS-Internal-Evaluation-QualityAssurance-Program.pdf

[46] Yakut, A., Akbıyıklı, R., İşçi sağlığ ve güvenliği yönetimi ile toplam kalite yönetimi sistemleri veri analizi incelemesi. SAU J. Sci. 17(1):97-103, 2013.

[47] Uryan, B., Toplam Kalite Yönetimi. Mevzuat Dergisi. 55, 2002.

[48] Bektaş, Ç., İşletmede İş Sağlığı ve Güvenliği Açısından Kalite Güvence Sistemlerinin Rolü. Emek ve Toplum. 8(8): 136-157, 2019.

[49] USHST [Internet]: Internal Evaluation Program Safety Assurance Check [cited 2019 Nov 12] Available from: http://www.ihst.org/portals/54/IHST_News/2014\%20IEP\%20Check\%20FINAL\%202 .pdf

[50] THRESHOLD [Internet]: Emergency Action Plans are critical for your company; [cited 2019 Nov3]. Available from: https://www.thresholdsecurity.com/Blog/EmergencyAction-Plans-are-critical-for-your-company/

[51] OSHA [Internet]: Emergency action plan; [cited 2019 Nov 2]. Available from: https://www.osha.gov/SLTC/etools/evacuation/eap.html

[52] Sawacha, E., Naoum, S., Fong, D., Factors affecting safety performance on construction sites. Int J Proj Manage. 17:309-315, 1999.

[53] Tam, C.M., Zeng, S.X., Deng, Z.M., Identifying elements of poor construction safety management in China. Saf Sci. 42:569-586, 2004.

[54] Aksorn, T., Hadikusumo, B.H.W., Critical success factors influencing safety program performance in Thai construction projects. Saf Sci. 46(4):709-727, 2008. 
[55] Mohamed, S., Safety climate in construction site environments. J Constr Eng Manage. 128(5):375-384, 2002.

[56] Safety+Health [Internet]: Reporting Near Misses; [cited 2019 Nov 10 9. Available from: https://www.safetyandhealthmagazine.com/articles/10994-reporting-nearmisses

[57] Industry Safe [Internet]: Why is near miss reporting important?; [cited 2019 Nov 10] Available from: https://www.industrysafe.com/blog/why-is-near-miss-reportingimportant

[58] Creative Safety Supply [Internet]: Why are safety signs important?, [cited 2019 Nov 12]. Available from: https://www.creativesafetysupply.com/qa/safety-signs/why-aresafety-signs-important

[59] Work Safe [Internet]: Traffic management in manufacturing; [cited 2019 Nov 19]. Available from: https://worksafe.govt.nz/topic-and-industry/manufacturing/trafficmanagement-manufacturing/ 
